\title{
PROJECTION OF DIAMETRIC DISTRIBUTION AND CARBON STOCK OF A MANAGED FOREST IN MANAUS/AM
}

\author{
Cintia Rodrigues de Souza ${ }^{1}$, Celso Paulo de Azevedo ${ }^{1}$, Luiz Marcelo Brum Rossi ${ }^{1}$, \\ Joaquim dos Santos ${ }^{2}$, Niro Higuchi ${ }^{2}$ \\ ${ }^{1}$ Forest Engineer, Dr., EMBRAPA Amazônia Ocidental, Manaus, AM, Brazil - cintia.souza@embrapa.br; \\ celso.azevedo@embrapa.br; marcelo.rossi@embrapa.br \\ ${ }^{2}$ Forest Engineer, Dr., INPA, Manaus, AM, Brazil - joca@inpa.gov.br; niro@inpa.gov.br
}

Received for publication 24/07/2013 - Accepted for publication 27/01/2014

\begin{abstract}
The projection of forest growth is important for forest management, to plan the subsequent cutting cycles and to show the tendencies that the forest will present in the future. This study evaluated the use of a stochastic model - the Markov Chain - in the projection of the future diametric distribution and carbon stock of a forest subjected to experimental selective logging in Manaus / AM. The data used were obtained from an experiment conducted since the 1980s by the Instituto Nacional de Pesquisas da Amazônia (Inpa). The forest inventories were conducted in the years 2005, 2007, 2009 and 2010. The main variable used was the diameter at breast height (DBH). The Markov Chain was used to project the diameter distribution and the carbon stock for 2015. With respect to the stock of carbon expected, this should exceed the existing stock in 2010, reaching about $157 \mathrm{t} / \mathrm{ha}$. With these results it is possible to conclude that, if the dynamics projection will be confirmed, the studied forest will continue growing and increasing its carbon stock, thus acting as a $\mathrm{CO}_{2}$ sink.

Keywords: Markov Chain; forest dynamics; forest management; climate change.
\end{abstract}

\section{Resumo}

Projeção da distribuição diamétrica e do estoque de carbono de floresta manejada na Amazônia. A prognose do crescimento de florestas é importante para o manejo florestal, para o planejamento dos ciclos de corte subsequentes e para mostrar as tendências que a floresta apresentará no futuro. Este trabalho avaliou a utilização de um modelo estocástico - a Cadeia de Markov - na projeção da distribuição diamétrica e do estoque de carbono de uma floresta submetida à exploração seletiva experimental em Manaus/AM. Foram utilizados dados de experimento desenvolvido desde 1980 pelo Instituto Nacional de Pesquisas da Amazônia (Inpa). Os inventários florestais foram realizados nos anos de 2005, 2007, 2009 e 2010. A principal variável utilizada foi o diâmetro à altura do peito (DAP). A Cadeia de Markov foi utilizada para projetar a distribuição diamétrica e o estoque de carbono para o ano de 2015. No que diz respeito ao estoque de carbono esperado, este deverá superar o estoque existente no ano de 2010, atingindo cerca de $157 \mathrm{t} / \mathrm{ha}$. Com esses resultados, pode-se concluir que, se for confirmada a projeção da dinâmica, a floresta estudada continuará crescendo e aumentando seu estoque de carbono, atuando, assim, como sumidouro de $\mathrm{CO}_{2}$.

Palavras-chave: Cadeia de Markov; dinâmica florestal; manejo florestal; mudanças climáticas.

\section{INTRODUCTION}

The study of tropical forest dynamics in the Amazon region, both in managed or natural forests, is a challenge, mainly because of its great heterogeneity. It is known that the accurate determination of the forest growth has great importance for the forest managers, and that basal area and volume of a forest stand can be easily calculated starting from the number of trees in each diameter class. The increase of these parameters can be estimated through the changes in the frequency of the individuals, which results in the change in the number of trees shifting from one diameter class to another, and through the recruitment and mortality rates (SANQUETTA et al. 1996; SANQUETTA et al., 1999).

The classic models of forest production were developed for temperate climate regions, where the 
most used variables are the site index and the age of the stand, variables that are practically unavailable in the Amazon forest, limiting the development of production models for this region (SANQUETTA et al., 1996; TEIXEIRA et al., 2007). According to Higuchi et al. (1997), about one million hectares of timber production stands are yearly undergoing some type of sustainable revenue forest management in the Amazon region. Without a production model, there is no possibility to plan the consecutive cutting cycles. One solution would then be the use of short period models, depending only on the previous situation, with the possibility of projection just for an immediately subsequent situation (BRUNER; MOSER JUNIOR, 1973; HIGUCHI et al., 1997).

Among the production models, transition matrixes are used in the projection and development of unevenly aged stands. Vanclay (1994) considered that the transition matrix may also be named Markov chain, Usher matrix and other generalizations, as being a logic extension of the population matrix projection method and, just like this one, it assumes that a tree encountered in a determined diameter class has the probability to migrate to another diameter class depending only on the current status. Along a period of time, a tree will remain in the same diameter class but, as it keeps developing, may migrate to other diameter classes and after reaching senescence, will eventually die. The migration between classes (recruiting, diameter class, mortality and harvesting) occurs according to a certain level of probability (TEIXEIRA et al., 2007; VASCONCELOS et al., 2009). Vasconcelos et al. (2009) affirm that, in general, trees have greater probability to maintain their diameter class mainly when short periods of time of about two years are considered,

In the field of forest management, transition matrix was first used by Usher (1966) in a Pinus sylvestris L. stand in Scotland, considering the diameter classes. Among the models based on transition matrixes, the Markov chain was used by various researchers for projections of unevenly aged stands, like Buongiorno and Mitchie (1980); Mitchie and Buongiorno (1984); Solomon et al. (1986); Azevedo et al. (1995), and others.

If the stochastic model has a finite number of states, it satisfies the markov property, or memoryless property. In other words the transition probability depends on a situation that is immediately previous to the current one and allows projections for an immediately subsequent situation (SOARES et al., 2009; VASCONCELOS et al., 2009). In this context, the diametric structure of a forest can be studied through the Markov chain, provided that the forest has a slow growth rate and the projection is made for short periods of time (SOARES et al., 2009).

Projections made with the Markov chain may be very helpful for the forest management, because they assist in the determination of the cutting cycle and allow to evaluate the tendencies that a forest will present in the next future (TEIXEIRA et al., 2007; VASCONCELOS et al., 2009), including for what is referred to the stock and dynamics of biomass and to the carbon stock. It is known that tropical forests may act as reserve or source of carbon for the atmosphere. There are various studies considering the tropical forests as carbon sinks, in other words they remove from the atmosphere more carbon than they emit (BOLIN et al., 2000; NABUURS; SCHELHAAS, 2002; CLARK, 2004; HIGUCHI et al., 2004; WOODBURY et al., 2007; HIGA et al., 2012). Trees act as carbon sink since they fix carbon during the photosynthesis process and stock the excess as biomass. On the other hand, human interaction in the forests (management) may have influence on the carbon dynamics, because of factors like the use of fossil fuels or logging and extraction of biomass. Meanwhile, in general, increasing the number of trees may potentially reduce carbon accumulation in the atmosphere (NOWAK; CRANE, 2002). According to Higuchi et al. (2009), the estimated carbon stock of the Brazilian Amazon forest is between 60 and 80 billion tons.

The aim of this study was to project the diametric distribution and the future carbon stock, using the Markov chain, in an experimentally managed tropical forest of the Central Amazon.

\section{MATERIAL AND METHODS}

The study was conducted using data originated by forest inventories made in an experiment located in the Estação Experimental de Silvicultura Tropical, belonging to the Instituto Nacional de Pesquisas da Amazônia (Inpa) in the municipality of Manaus (AM), between the geographical coordinates $2^{\circ} 37^{\prime}$ to $2^{\circ} 38^{\prime}$ latitude South and $60^{\circ} 09^{\prime}$ and $60^{\circ} 11^{\prime}$ longitude West.

The experiment is part of a project called "Ecologic Management and Harvesting of the Tropical Rainforest" (Manejo Ecológico e Exploração da Floresta Tropical Úmida), established in 1980 and 
covering an area of 96 hectares, which had the objective to test the possibilities to manage a tropical rainforest submitted to a natural regeneration system and to determine cutting cycles, together with the projections of production per species (HIGUCHI et al., 1985).

The forest area classification is terra firme tropical rainforest, typical of the Central Amazon (HIGUCHI et al., 1997). The forest coverage is dense, rarely with uniform superior stratum, being many times modified by patches of open forest, where the herbaceous and shrubby vegetation stratums are composed by natural regeneration of the tree species, small size palm trees and non-vascular plants (Radar da Amazônia - RADAM, 1978).

According to the Köppen classification, the climate of the region is "Amw" type, hot and humid during the whole year, with high temperature, rainfall and relative humidity. The mean annual temperature is $26.7^{\circ} \mathrm{C}$ and the mean annual relative humidity is $83 \%$ (Instituto Nacional de Meteorologia - INMET, 1992). The annual rainfall reaches $2,500 \mathrm{~mm}$, being mostly concentrated between December and May.

The most representative soil of the region is the yellow alic latosol, which covers the surface of plateaus, with the presence of a porous horizon in the middle, situated between two low porosity horizons. Soil if formed by tertiary sediments of the Barreiras Group, which are constituted by resistant minerals, like kaolinite, quartz, iron and aluminum oxide or hydroxide (CHAUVEL, 1982).

The experimental design was in randomized blocks, the surface of each block was 24 ha $(400 \mathrm{x}$ $600 \mathrm{~m})$. Each block contained six treatments, each treatment with a surface of 4 ha $(200 \mathrm{x} 200 \mathrm{~m})$, corresponding to the different logging levels applied in 1987 (basal reduction rates of $0 \%, 25 \%, 50 \%$ and $75 \%)$. The permanent stands, each with a surface of 1 ha $(100 \times 100 \mathrm{~m})$, were installed in the center of the treatment areas, in other words each treatment had a $100 \mathrm{~m}$ wide buffer zone, which eliminates possible edge effects. All trees with DBH greater than or equal to $10 \mathrm{~cm}$ were measured. Forest inventories were performed in the years 2005, 2007, 2009 and 2010.

With data of the diameter at breast height (DBH) obtained in the performed inventories, it was possible to make a projection of the forest population dynamics using the Markov Chain. In the first data collection made in 2005, all individuals with DBH greater than $10 \mathrm{~cm}$ found in the stands were measured. In the second data collection, which took place in 2007, again were measured all the individuals registered in the first inventory (thus evaluating the diametric growth, which allowed or not the migration to another diameter class). Furthermore, also the individuals that reached a DBH of $10 \mathrm{~cm}$ were measured and registered (recruiting), and were also identified all the registered individuals that had died of natural causes in the period between 2005 and 2007 (mortality).

Basing on the measures made in 2005 and 2007, projections for 2009 were produced, with the aim to compare these projections with the field measurements done that same year. The transition matrix with migration probabilities per diameter class was built, with the probability of a tree in the first diameter class to remain in the same class after the two years interval, or to grow, towards the next class. This way, the projection of the frequency for 2009 per each diameter class was possible (considering the two year time interval). Finally, basing on the measurements made in 2005 and 2010, the projection for 2015 was defined, considering that the Markov chain proved to be a good model to make the projection for the dynamics of the studied forest.

Trees of the forest stand were divided into ten diameter classes. During the growing period considered in this study, two years $(\theta$, theta), trees of a given diameter class I could remain in the same class, migrate to a greater class or also die along the two years considered in the analysis.

The matrix notation of the number of surviving trees, in each diameter class, is made as follows:

$$
\begin{gathered}
Y=\left(y_{1 t}, y_{2 t}, \cdots, y_{n t}\right), \text { or } \\
\underset{\sim}{Y}=\left[y_{i t}\right], \mathrm{i}=1,2, \ldots, 10 \text { diameter classes. }
\end{gathered}
$$

To accompany growth and mortality of the trees, are to be considered:

$\mathrm{a}_{\mathrm{i}}=$ probability that a tree that is alive and into a diameter class $\mathrm{i}$, in the time $t$, remains alive and in the same diameter class $i$, at the time $t+1$.

$b_{i}=$ probability that a tree that is alive in a diameter class $i-1$, in the time $t$, remains alive and in the diameter class $\mathrm{i}$, at the time $\mathrm{t}+1$. 
$\mathrm{m}_{\mathrm{i}}=$ probability that a tree that is alive in a diameter class $\mathrm{i}$, at the time $\mathrm{t}$, is found dead at the time $t+1$.

$m_{i}=1-a_{i}-b_{i+1}$, for $i=1, \ldots . n-1$

$\mathrm{m}_{\mathrm{n}}=1-\mathrm{n}_{\mathrm{a}}$ (last class)

Situation of the stand at the time $t+1$ is determined by the situation at the time $t$ and by the class recruitment happened along the two year time interval, adopting the following equations:

Simultaneously for $i \geq 3$

$$
\begin{gathered}
y_{1 t+\theta}=I_{t}+a_{1}\left(y_{1 t}\right) \quad \text { and } \\
y_{2 t+\theta}=b_{2}\left(y_{1 t}\right)+a_{2}\left(y_{2 t}\right) \\
I_{t}=\text { recruitment }\left(\mathrm{I}_{\mathrm{t}} \geq 0\right) .
\end{gathered}
$$

$$
y_{n t+\theta}=b_{n}\left(y_{(n-1) t}\right)+a_{n}\left(y_{n t}\right)
$$

where: $y_{1 t+\theta}=$ number of alive trees in class 1 , at the time $t+\theta$

$\mathrm{y}_{1 \mathrm{t}}=$ number of alive trees in class 1 , at the time $\mathrm{t}$

The model in matrix form can be written as follows:

$$
\left[\begin{array}{c}
y_{1 t+\theta} \\
y_{2 t+\theta} \\
y_{3 t+\theta} \\
y_{4 t+\theta} \\
\bullet \\
\bullet \\
\bullet \\
y_{n t+\theta}
\end{array}\right]=\left[\begin{array}{cccccccccc}
a_{1} & \bullet & \bullet & \bullet & \bullet & \bullet & \bullet & \bullet & & 0 \\
b_{2} & a_{2} & 0 & 0 & \bullet & \bullet & \bullet & \bullet & & 0 \\
0 & b_{3} & a_{3} & 0 & \bullet & \bullet & \bullet & \bullet & & 0 \\
0 & 0 & b_{4} & a_{4} & \bullet & \bullet & \bullet & \bullet & & 0 \\
\bullet & \bullet & \bullet & \bullet & \bullet & \bullet & \bullet & \bullet & & \bullet \\
\bullet & \bullet & \bullet & \bullet & \bullet & \bullet & \bullet & \bullet & & \bullet \\
\bullet & \bullet & \bullet & \bullet & \bullet & \bullet & \bullet & \bullet & & \bullet \\
0 & 0 & 0 & 0 & \bullet & \bullet & \bullet & \bullet & b_{n} & a_{n}
\end{array}\right] \bullet\left[\begin{array}{c}
y_{1 t} \\
y_{2 t} \\
y_{3 t} \\
y_{4 t} \\
\\
\\
y_{n t}
\end{array}\right]+\left[\begin{array}{c}
I_{t} \\
0 \\
0 \\
0 \\
0 \\
\\
\\
\\
\\
\\
\end{array}\right]
$$

Using the matrix notation, the expression assumes a more compact form, as follows:

$$
Y_{t+\theta}=M\left(\underset{\sim}{y_{i t}}\right)+\underset{\sim}{c}
$$

where: $\mathrm{M}$ and $\mathrm{c}$ are the matrix and the column vector of the recruitment (entrance).

The model was used to project the dynamics of the stand, basing on the migration probabilities. The observed and estimated frequencies were compared through the Chi-squared test.

To determine the biomass and carbon rates, equations proposed by Silva (2007) were used.

$$
\begin{aligned}
\mathrm{PF}_{\mathrm{abg}}=2,2737 \times \mathrm{DAP}^{1,9156} \quad\left(\mathrm{R}^{2}=0,85\right) \\
\mathrm{PF}_{\mathrm{tot}}=2,7179 \times \mathrm{DAP}^{1,8774} \quad\left(\mathrm{R}^{2}=0,94\right) \\
\mathrm{PS}_{\mathrm{abg}}=\left(\mathrm{PF}_{\mathrm{abg}}\right) \times 0,592 \\
\mathrm{PS}_{\mathrm{tot}}=\left(\mathrm{PF}_{\mathrm{tot}}\right) \times 0,584 \\
\mathrm{C}_{\mathrm{abg}}=\left(\mathrm{PS}_{\mathrm{abg}}\right) \times 0,485 \\
\mathrm{C}_{\mathrm{tot}}=\left(\mathrm{PS}_{\mathrm{tot}}\right) \times 0,485
\end{aligned}
$$

where: $\mathrm{PF}_{\mathrm{abg}}=$ fresh biomass above the ground level; 
$\mathrm{P}_{\text {tot }}=$ total fresh biomass (above ground level + big roots);

$\mathrm{PS}_{\mathrm{abg}}=$ dry biomass above the ground level;

$\mathrm{PS}_{\text {tot }}=$ total dry biomass;

$\mathrm{C}_{\mathrm{abg}}=$ carbon reserves in vegetation above the ground level;

$\mathrm{C}_{\mathrm{tot}}=$ total carbon reserves (above the ground level + big roots).

\section{RESULTS AND DISCUSSIONS}

Table 1 shows the matrix containing the frequency by diameter class between the years 2005 and 2007 , showing the number of trees that remained in the same diameter class, the ones that migrated to a greater class and the ones that died.

Table 1. Frequency of individuals by diameter class between the years 2005 and 2007. The states represent the center of each diameter class and $\mathrm{M}$ represents the observed mortality in the period.

Tabela 1. Frequência por classe diamétrica dos indivíduos no período entre 2005 e 2007. Os estados representam o centro de cada classe diamétrica e $\mathrm{M}$ representa a mortalidade observada no período.

\begin{tabular}{lccccccccccc}
\hline $\begin{array}{l}\text { Diameter } \\
\text { class }\end{array}$ & $\mathbf{1 5}$ & $\mathbf{2 5}$ & $\mathbf{3 5}$ & $\mathbf{4 5}$ & $\mathbf{5 5}$ & $\mathbf{6 5}$ & $\mathbf{7 5}$ & $\mathbf{8 5}$ & $\mathbf{9 5}$ & $\mathbf{2 1 0 0}$ & $\mathbf{2 0 0 5}$ \\
\hline 15 & 3758 & & & & & & & & & & 3758 \\
25 & 109 & 1280 & & & & & & & & & 1389 \\
35 & & 60 & 548 & & & & & & & & 608 \\
45 & & & 21 & 248 & & & & & & & 269 \\
55 & & & & 12 & 85 & & & & & & 97 \\
65 & & & & & 8 & 41 & & & & & 49 \\
75 & & & & & & 1 & 17 & & & & 18 \\
85 & & & & & & & & 8 & & & 8 \\
95 & & & & & & & & & 3 & & 3 \\
$\geq 100$ & 142 & 44 & 16 & 6 & 6 & 1 & 0 & 0 & 0 & 0 & 215 \\
$\mathrm{M}$ & 4009 & 1384 & 585 & 266 & 99 & 43 & 17 & 8 & 3 & 3 & 6202 \\
2007 & & & & & & &
\end{tabular}

${ }^{1}$ Represents the centers of the diameter class where the centers of class shown horizontally are referred to year 2005 and the centers of class shown vertically are referred to year 2007 .

This means that, between 2005 and 2007, 3758 individuals that were in the $1^{\text {st }}$ diameter class in 2005 , remained in same class when measured in $2007(10 \mathrm{~cm} \leq \mathrm{DBH} \leq 20 \mathrm{~cm}$, with center of class equal to $15 \mathrm{~cm}) ; 109$ grew enough to migrate to the $2^{\text {nd }}$ diameter class $(20 \mathrm{~cm} \leq \mathrm{DBH} \leq 30 \mathrm{~cm}$, with center of class equal to $25 \mathrm{~cm}$ ). In the same way, 142 individuals of the first diameter class died along the assessed period. The same procedure can be extended to all the other diameter classes shown.

Projected values for the year 2007 were then obtained, for each diameter class (Table 2). The estimated values were summed to the recruitments occurred in the same period. In this case there were 210 recruitments in the first class and no recruitments in the other diameter classes. These values were compared with the actual values measured during the inventory performed in the same year, through the Chi-squared test $\left(\chi^{2}\right)$. Since the calculated value for $\chi^{2}$ (3.57) was smaller than the tabulated values (16.919 at 5\% level of probability and 14.684 at $1 \%$ level of probability), it is possible to conclude that there is no significant difference between the observed values and the projected values for the year 2007.

The probability matrix for year 2009 is shown in Table 3 . This is to say that the probability for a tree in the first diameter class to remain in the same class after the two years interval (from 2007 to 2009) is $87 \%$, and so on.

Table 3 shows the transition probability matrix by diameter class for the year 2009 . This is to say that the probability for a tree in the first diameter class to remain in the same class after the two years interval (between 2007 and 2009), is 87\%, the probability for a tree in the first diameter class to migrate to the second class is $5 \%$, and so on. 
Table 2. Frequencies observed and estimated (including recruitments) for the year 2007, by diameter class and values of $\chi^{2}$. As $\chi^{2}$. $(1 \%)=14,684$ and $\chi 2 .(5 \%)=16,919$.

Tabela 2. Frequências observada (incluindo o ingresso e descontando a mortalidade) e estimada para o ano de 2007, por classe de diâmetro e valores de $\chi^{2}$. Sendo $\chi^{2} \cdot(1 \%)=14,684$ e $\chi^{2} .(5 \%)=$ 16,919 .

\begin{tabular}{llll}
\hline Center of class & Observed Freq. 2007 & Projected Freq. 2007 & $\boldsymbol{\chi}^{2}$. \\
\hline 15 & 3826 & 3758 & 1.23 \\
25 & 1345 & 1389 & 1.39 \\
35 & 592 & 608 & 0.42 \\
45 & 263 & 269 & 0.13 \\
55 & 91 & 97 & 0.37 \\
65 & 48 & 49 & 0.02 \\
75 & 18 & 18 & 0 \\
85 & 8 & 8 & 0 \\
95 & 3 & 3 & 0 \\
$\geq 100$ & 3 & 3 & 0 \\
& & & 3.57 \\
\hline
\end{tabular}

Table 3. Probability (Stochastic) matrix for 2009.

Tabela 3. Matriz de transição probabilística para 2009.

\begin{tabular}{lcccccccccc}
\hline Class & $\mathbf{1 5}$ & $\mathbf{2 5}$ & $\mathbf{3 5}$ & $\mathbf{4 5}$ & $\mathbf{5 5}$ & $\mathbf{6 5}$ & $\mathbf{7 5}$ & $\mathbf{8 5}$ & $\mathbf{9 5}$ & $\geq \mathbf{1 0 0}$ \\
\hline 15 & 0.87 & & & & & & & & & \\
25 & 0.05 & 0.85 & & & & & & & & \\
35 & 0.001 & 0.08 & 0.87 & & & & & & & \\
45 & & 0.001 & 0.06 & 0.86 & & & & & & \\
55 & & & 0.002 & 0.08 & 0.73 & & & & & \\
65 & & & & 0.003 & 0.14 & 0.90 & & & & \\
75 & & & & & 0.002 & 0.04 & 1 & & & \\
85 & & & & & & & & 1 & 1 & \\
95 & & & & & & & & & & 0.56 \\
$\geq 100$ & & & & & & & &
\end{tabular}

The projected values for 2009 were obtained and summed to the recruitments that occurred within this time interval, which were 186 individuals between 2007 and 2009, exclusively in the first diameter class. Through the Chi-squared test $\left(\chi^{2}\right)$, the projected and observed frequency were compared. Since the calculated value for $\chi^{2}(7.19)$ was smaller than the tabulated values $(16.919$ at $5 \%$ of probability and 14.684 at $1 \%$ of probability), it was concluded that there was no significant difference between the values observed in field and the calculated values for the year 2009, thus validating the projection of the dynamics with the Markov chain for the assessed forest area.

The projection of the diametric distribution with the Markov chain have already been studied by various researchers. Sanquetta et al. (1996) used transition matrixes to evaluate a natural forest in Japan, in the years 1984 and 1987. These authors made projections referred to the basal area and the total number of trees in the stand, concluding that these two parameters came back to the initial conditions 12 years after logging.

Teixeira et al. (2007) assessed the dynamic of a natural unlogged forest in the Manaus/AM region and projected the forest dynamics using the Markov chain, using data from two forest inventories performed in that area in the years 2000 and 2004. To confirm the possibility to use the Markov probabilistic transition chain, the diametric distribution of the forest was used as main variable. A projection of the diametric distribution for the year 2008 was defined, and the Chi-squared test showed that there was no significant difference between the projected and observed frequencies of the distribution of trees in each diameter class for that year.

Vasconcelos et al. (2009), studying a selectively logged forest in the Acre state, also used the transition probability matrix to define a projection of the diametric distribution. Data from forest 
inventories performed in 1997, 1999 and 2001 were used. Considering the year 2001, the diametric distribution did not show statistically significant difference between the projected and observed frequencies. It was then defined a projection for two further time intervals. That is to say for the year 2005. This projection indicated that the mortality rate in 2005 would be close to the previous (2001) and, if the recruitment rate of 2005 would be equal to 2001, the total number of trees would be greater than what observed in 2001. Thus, as in this work, the authors confirmed that the use of the Markov Chain is an important instrument to make projections of the future behavior in managed forests of the Amazon region.

\section{Projection for the year 2015}

In table 4 is shown the initial matrix of transition probability by diameter class. Through this matrix it is possible to predict that the probability of a tree in the first diameter class to remain in the same class after the five years interval is $83 \%$ and the probability of a tree in the first diameter class to migrate to the second is $6 \%$, and so on.

Table 4. Initial matrix of transition probabilities, by diameter class, for the period between 2005 and 2007.

Tabela 4. Matriz inicial de probabilidade de transição, por classe diamétrica, para o período entre 2005 e 2007.

\begin{tabular}{lcccccccccc}
\hline Class & $\mathbf{1 5}$ & $\mathbf{2 5}$ & $\mathbf{3 5}$ & $\mathbf{4 5}$ & $\mathbf{5 5}$ & $\mathbf{6 5}$ & $\mathbf{7 5}$ & $\mathbf{8 5}$ & $\mathbf{9 5}$ & $\geq \mathbf{1 0 0}$ \\
\hline 15 & 0.83 & & & & & & & & & \\
25 & 0.06 & 0.83 & & & & & & & & \\
35 & & 0.09 & 0.83 & & & & & & & \\
45 & & & 0.10 & 0.85 & & & & & & \\
55 & & & & 0.09 & 0.76 & & & & & \\
65 & & & & & 0.14 & 0.88 & & & & \\
75 & & & & & & 0.09 & 0.76 & & & \\
85 & & & & & & & 0.24 & 0.75 & & \\
95 & & & & & & & & 0.13 & 1.00 & \\
$\geq 100$ & & & & & & & & & & 0.75 \\
\hline
\end{tabular}

The projected values for the year 2010 were obtained, for each diameter class, and summed to the recruitments occurred in this period. In this case there were 493 recruitments, all in the first diameter class. These values were compared, through the Chi-squared test $\left(\chi^{2}\right)$, with the actual values measured during the inventory of 2010 . Since the calculated value of $\chi^{2}(14.33)$ was smaller than the tabulated values (16.919 at $5 \%$ of probability and 14.684 at $1 \%$ of probability), it is possible to conclude that there is no significant difference between the calculated and measured values for the year 2010 (Table 5).

Table 5. Observed and estimated frequencies (including recruitments) for the year 2010, by diameter class and values of $\chi^{2}$. As $\chi^{2}$. $(1 \%)=14,684$ and $\chi 2$. $(5 \%)=16,919$.

Tabela 5. Frequências observada e estimada (incluindo o ingresso) para o ano de 2010, por classe de diâmetro e valores de $\chi^{2}$. Sendo $\chi^{2} .(1 \%)=14,684$ e $\chi^{2} .(5 \%)=16,919$.

\begin{tabular}{llll}
\hline Center of class & Observed Freq. & Projected Freq. & $\chi^{2}$. \\
\hline 15 & 3381 & 3325 & 0.94 \\
25 & 1277 & 1385 & 8.42 \\
35 & 563 & 606 & 3.05 \\
45 & 267 & 282 & 0.79 \\
55 & 90 & 100 & 1.00 \\
65 & 51 & 52 & 0.01 \\
75 & 17 & 17 & 0.00 \\
85 & 9 & 10 & 0.10 \\
95 & 4 & 4 & 0.00 \\
$\geq 100$ & 3 & 3 & 0.00 \\
& & & $\mathbf{1 4 . 3 1}$ \\
\hline
\end{tabular}


Since it was proven that it is safe to make projections using the Markov Chain in the studied forest area, the study moved on to obtain the projected values for the year 2015. Recruitments occurred along this interval of time (493 individuals), all of them in the first diameter class, were summed to the calculated values. Projected values for the year 2015, by diameter class, are shown in Table 6 .

Table 6. Estimated frequencies by diameter class for the year 2015.

Tabela 6. Frequências estimadas, por classe diamétrica, para o ano de 2015.

\begin{tabular}{llll}
\hline Center of class & Estimated Freq. & Recruitments & Final Estim. Freq. \\
\hline 15 & 2757 & 493 & 3250 \\
25 & 1359 & & 1359 \\
35 & 625 & 625 \\
45 & 298 & 298 \\
55 & 102 & 102 \\
65 & 60 & 60 \\
75 & 18 & 18 \\
85 & 12 & 12 \\
95 & 5 & 5 \\
$\geq 100$ & 2 & 2 \\
\hline
\end{tabular}

Basing on the projected frequencies for the year 2015 it was then possible to estimate the expected carbon stock of the forest for that year. Comparing with the measured stocks of the location it is possible to conclude that, if the dynamics of the projection will be confirmed, the forest will maintain its ascending curve and will go on with the carbon sequestration in the next years, increasing its stock to approximately $157 \mathrm{t} \mathrm{ha}^{-1}$. In Table 7 the carbon stocks per each assessed treatment are shown (control unlogged, and basal area reduction of 25\%, 50\% and 75\%), for the years 2005, 2007 and 2010, in comparison with the projected 2015 stock.

Table 7. Carbon stocks $\left(\mathrm{t} \mathrm{ha}^{-1}\right)$ for the assessed reduction of basal area treatments in 2005, 2007 and 2010, and projection for 2015.

Tabela 7. Estoques de carbono (t.ha ${ }^{-1}$ ) para os tratamentos de redução de área basal avaliados, nos anos de 2005, 2007 e 2010, e projeção para 2015.

\begin{tabular}{|c|c|c|c|c|c|}
\hline \multirow{2}{*}{ Year } & \multicolumn{4}{|c|}{ Carbon stock (t. ha $\left.^{-1}\right)$} & \multirow{2}{*}{ Mean } \\
\hline & Unlogged & $25 \%$ & $\mathbf{5 0 \%}$ & $75 \%$ & \\
\hline 2005 & 158.7 & 143.2 & 146.6 & 148.4 & 149.2 \\
\hline 2007 & 162.6 & 143.9 & 149.8 & 150.8 & 151.8 \\
\hline 2010 & 164.8 & 143.7 & 151.5 & 150.2 & 152.6 \\
\hline \multicolumn{5}{|c|}{ Projection for 2015} & 157.0 \\
\hline
\end{tabular}

Analyzing data of Table 7, it is possible to conclude that the stock of the unlogged forest

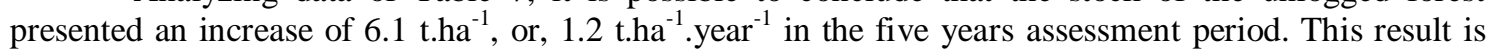
similar to the studies performed by Higuchi et al. (2004), who studying a primary forest in the region of Manaus/AM, concluded that the forest performs carbon sequestration with a rate of $1.2 \mathrm{t} \mathrm{ha}^{-1}$ year $^{-1}$, mainly due to the individual growth of trees existing in the system, compensating the losses due to the natural mortality. The reduction of stocked carbon between the years 2007 and 2010, in the 25\% and $75 \%$ basal area reduction treatments, are due to the greater mortality rates that were observed in these two treatments.

\section{CONCLUSIONS}

- The Markov Chain confirmed to be a valid instrument to project the diametric distribution of the studied forest. With relation to the future carbon stock it is possible to conclude that this will keep growing, at least until 2015, so that the forest keeps working as a carbon sink and thus contributes to minimize the effects of the global climate changes. 


\section{REFERENCES}

AZEVEDO, C. P.; SOUZA, A. L.; JESUS, R. M. Um modelo de matriz de transição para prognose do crescimento de um povoamento natural remanescente não manejado de Mata Atlântica. Revista Árvore, Viçosa, v. 19, n. 2, p. 187 - 199, 1995.

BOLIN, B.; SUKUMAR, R.; CIAIS, P. CRAMER, W.; JARVIS, P.; KHESHGI, H.; NOBRE, C.; SEMENOV, S.; STEFFEN, W. Global Perspective. In: WATSON, R. T.; NOBLE, I. R.; BOLIN, B.; RAVINDRANATH, N. H.; VERARDO, D. J.; DOKKEN, D. J. Land use, land use change and forestry - a special report of the IPCC. Cambridge: Cambridge University Press, 2000. 377 p.

BRUNER, H. D.; MOSER JR, J. W. A Markov Chain approach to the prediction of diameter distributions in uneven-aged forest stands. Canadian Journal of Forest Research, Ottawa, v. 3, p. 409 - 417,1973.

BUONGIORNO, J.; MITCHIE, B. R. A matrix model of uneven-aged forest management. Forest Science, Lawrence, v. 26, n. 4, p. 609 - 625, 1980.

CHAUVEL, A. Os latossolos amarelos, álicos, argilosos, dentro dos ecossistemas das bacias experimentais do INPA e da região vizinha. Acta Amazonica, Manaus, v. 12, n. 3, p. 47 - 60, 1982.

CLARK, D. A. Sources or sinks? The responses of tropical forests to current and future climate and atmospheric composition. Philosophical Transactions of the Royal Society of London B, London, v. 359, p. 477 - 491, 2004.

HIGA, R. C. V.; XAUD, H. A. M.; ACCIOLY, L. J. O.; LIMA, R. M. B.; VASCONCELOS, S. S.; RODRIGUES, V. G. S.; CARVALHO, C. J. R.; SOUZA, C. R.; LEONIDAS, F. C.; TONINI, H.; FERRAZ, J. B. S.; XAUD, M. R.; MOURÃO JR, M.; COSTA, R. S. C. Estoque de biomassa em florestas plantadas, sistemas agroflorestais, florestas secundárias e caatinga. In: LIMA, M. A.; BODDEY, R. M.; ALVES, B. J. R.; MACHADO, P. L. O. A.; URQUIAGA, S.[Eds.]. Estoques de carbono e emissões de gases de efeito estufa na agropecuária brasileira. Brasília: Embrapa, p. 105 - 158. 2012.

HIGUCHI, N.; JARDIM, F.C.; SANTOS, J.; BARBOSA, A. Bacia 3-Inventário Florestal Comercial. Acta Amazonica, Manaus, v. 15, n. 3 - 4, p. 327 - 369, 1985.

HIGUCHI, N.; SANTOS, J.; RIBEIRO. R. J.; FREITAS, J. V.; VIEIRA, G.; CÖIC, A.; MINETTE, L. J. Crescimento e Incremento de uma Floresta Amazônica de Terra firme Manejada Experimentalmente In: INPA/DFID (Eds.). Biomassa e nutrientes florestais, Relatório final do projeto BIONTE. p. 89 - 132. 1997.

HIGUCHI, N.; CHAMBERS, J.; SANTOS, J.; RIBEIRO, R. J.; PINTO, A. C. M.; SILVA, R. P. da; ROCHA, R. DE M.; TRIBUZY, E. S. Dinâmica e balanço do carbono da vegetação primária da Amazônia central. Floresta, Curitiba, v. 34, n. 3, p. 295 - 304, 2004.

HIGUCHI, N.; PEREIRA, H. S.; SANTOS, J.; LIMA, A. J. N.; HIGUCHI, F. G.; HIGUCHI, M. I. G.; AYRES, I. G. S. S. Governos locais amazônicos e as questões climáticas globais. Edição dos autores, 104 pp. 2009.

INSTITUTO NACIONAL DE METEOROLOGIA (INMET.). Normas Climatológicas. Brasília: Ministério da Agricultura e Reforma Agrária. 84 p. 1992.

MITCHIE, B. R.; BUONGIORNO, J. Estimation of a matrix model of forest growth from remeasured permanent plots. Forest Ecology and Management, Madison, v. 18, p. 127 - 135, 1984.

NABUURS, G. J.; SCHELHAAS, M. J. Carbon profiles of typical forest types across Europe assessed with $\mathrm{CO}_{2}$ FIX. Ecological Indicators, Philadelphia, v. 1, n. 3, p. 213 - 223, 2002.

NOWAK, D. J.; CRANE, D. E. Carbon storage and sequestration by urban trees in the USA. Environmental Pollution, Philadelphia, v. 116, p. 381 - 389, 2002.

Radar na Amazônia (RADAM). Programa de Integração Nacional. Levantamentos de Recursos Naturais. v. 18 (Manaus) - Radam (projeto) DNPM, Ministério das Minas e Energia. Brasil. 626 pp. 1978. 
SANQUETTA, C. R.; BRENA, D. A.; ANGELO, H.; MENDES, J. B. Matriz de transição para simulação da dinâmica de florestas naturais sob diferentes intensidades de corte. Ciência Florestal, Santa Maria, v. 6, n. 1, p. $65-78,1996$.

SANQUETTA, C. R.; ARCE, J. E.; GOMES, F.; CRUZ, E. C. Evaluación y simulación precoces del crescimento de rodales de Pinus taeda L. com matrices de transición. Revista de Ciencias Forestales, Santiago, v. 7, p. 31 - 42, 1999.

SILVA, R. P. Alometria, estoque e dinâmica da biomassa de florestas primárias e secundárias na região de Manaus (AM). 152 f. Tese (Doutorado em Ciências de Florestas Tropicais) - Instituto Nacional de Pesquisas da Amazônia (INPA/UFAM), Manaus, 2007.

SOARES, C. P. B.; DEMOLINARI, R. A.; LEITE, H. G.; SOUZA, A. L. Predição do crescimento em povoamentos clonais de eucalipto não desbastados utilizando matrizes de transição não estacionárias. Revista Árvore, Viçosa, v. 33, n. 5, p. 831 - 840, 2009.

SOLOMON, D. S.; HOSMER, R. A.; HAYSLETT JR., H. T. A forest two-stage matrix model for predicting growth of forest stands in the northeast. Canadian Journal of Forest Research, Ottawa, v. 16, p. $521-508,1986$.

TEIXEIRA, L. M.; CHAMBERS, J. Q.; SILVA, A. R.; LIMA, A. J. N.; CARNEIRO, V. M. C.; SANTOS, J.; HIGUCHI, N. Projeção da dinâmica da floresta natural de terra-firme, região de ManausAM, com o uso da cadeia de transição probabilística de Markov. Acta Amazonica, Manaus, v. 37, n. 3, p. 377 - 384, 2007.

USHER, M. B. A matrix approach to the management of renewable resources, with special reference to selection forests. Journal of Applied Ecology, London, v. 3, p. 355 - 367, 1966.

VANCLAY, J. Modelling forest growth and yield: applications to mixed tropical forests. CAB International, London, 312 p. 1994.

VASCONCELOS, S. S.; HIGUCHI, N.; OLIVEIRA, M. V. N. Projeção da distribuição diamétrica de uma floresta explorada seletivamente na Amazônia Ocidental. Acta Amazonica, Manaus, v. 39, n. 1, p. $71-80,2009$.

WOODBURY, P. B.; SMITH, J. E.; HEATH, L. S. Carbon sequestration in the U.S. forest sector from 1990 to 2010. Forest Ecology and Management, Madison, v. 241, p. 14 - 27, 2007. 